\title{
THE EFFECT OF THE MODIFICATION OF THE BASE PROFILE ANGLE OF THE X-ZERO GEAR DRIVES FOR THE TCA PARAMETERS
}

\author{
SÁNDOR BODZÁS
}

Department of Mechanical Engineering, Faculty of Engineering, University of Debrecen, Ótemetö u. 2-4, H-4028 Debrecen, Hungary

E-mail: bodzassandor@eng.unideb.hu

The aim of this research is the analysis of the effect of the modification of the base profile angles of x-zero gear drives for the TCA parameters. We analyze the normal stress, the normal deformation and the normal elastic strain on the connecting zone of the gear pairs. Based on the received results we create diagrams which show the fluctuation of the analyzed TCA parameters in the function of the changing of the selected parameter of the x-zero gear drives. After the analysis we determine the consequences and select the appropriate variant.

Keywords: x-zero gear drive, base profile angle, TCA, normal, modification

\section{Introduction}

The spur gears are widely used in many mechanical constructions, that is why the tooth contact research of them is important because of the geometric development and optimization [5, 6, 10, 13] (Fig. 1).
The main steps of the gear generation process [17, 9, 10, 12, 13]:

- Gear designing: determination of the geometric parameters, calculation of the profile points, creation of the computer aided model (CAD), TCA analysis, etc.

- Gear manufacturing: selection of the necessary technology, selection of the necessary cutting
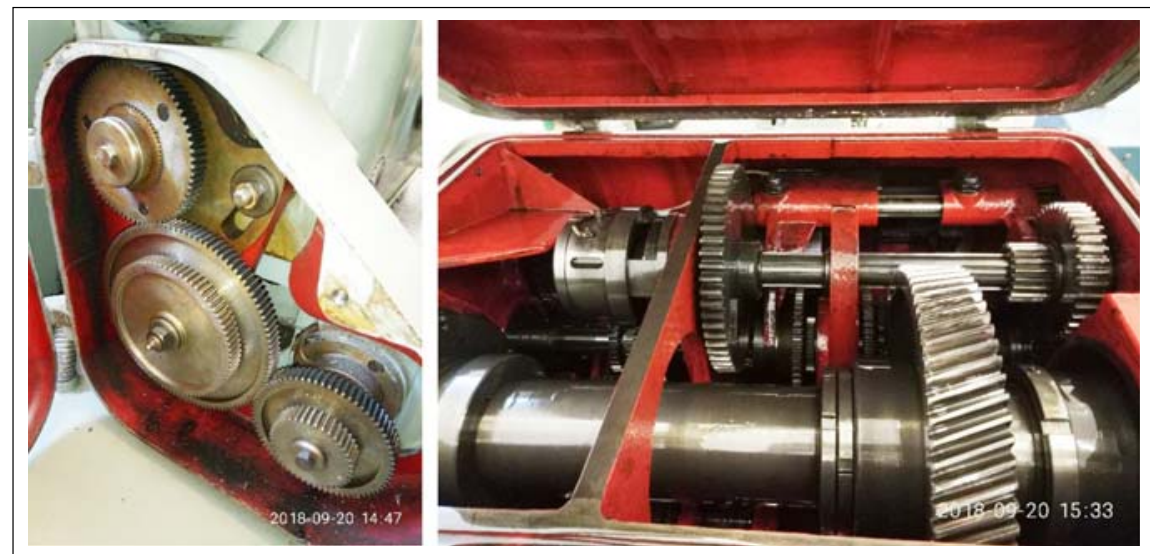

Fig. 1. The application of spur gears in the case of primary gear box of a turning machine (Department of Mechanical Engineering, University of Debrecen)

Open Access statement. This is an open-access article distributed under the terms of the Creative Commons Attribution 4.0 International License (https://creativecommons.org/licenses/by/4.0/), which permits unrestricted use, distribution, and reproduction in any medium, provided the original author and source are credited, a link to the CC License is provided, and changes - if any - are indicated. (SID_1) 
tool, determination of the main steps of the manufacturing process, etc.

- Gear measuring process: beat examination, real connection analysis, noise and vibration analysis, etc.

The aim of the TCA (Tooth Contact Analysis) is the determination and analysis of the mechanical parameters of the gear connection (normal stress, normal, deformation, normal, strain, etc.) [7-9]. Based on these results the evaluations of the disposition of the established mechanical parameters are very important because of the appropriate selection of the usable gear pair for a given technological task [7-9]. The results are given a way for the other construction development possibilities of the gears.

\section{Designing of spur gears having different base profile angles}

The tooth connection always occurs on the common normal line of the tooth arc. This line is called line of action. This line is a tangent line of both base circle di-
The main property of the x-zero gear drive is the standard centre distance along which the elements could be connected. In this case the rolling diameter and the pitch circle diameter are the same $[6,9,10,12,13]$.

Knowing the pitch circle diameters the base circle diameters could be calculated $[6,12,13]$ :

$$
d_{b_{1,2}}=d_{1,2} \cos \alpha_{0}
$$

The equations of the involute profile curves (Fig. 3):

$$
\begin{aligned}
x_{1} & =\frac{d_{1} \cos \alpha_{0}}{2}(\cos \beta+\beta \sin \beta), \\
& =\frac{{ }_{2} \cos 0}{}(\sin \beta-\beta \cos \beta) .
\end{aligned}
$$

In case of the determination of the profile curve the $\beta$ parameter is the changing parameter which has to be changed between the base circle diameter and the tip circle diameter of the given gear.

Five types of gear pairs have been designed by our developed computer software $[1,2]$. Knowing the

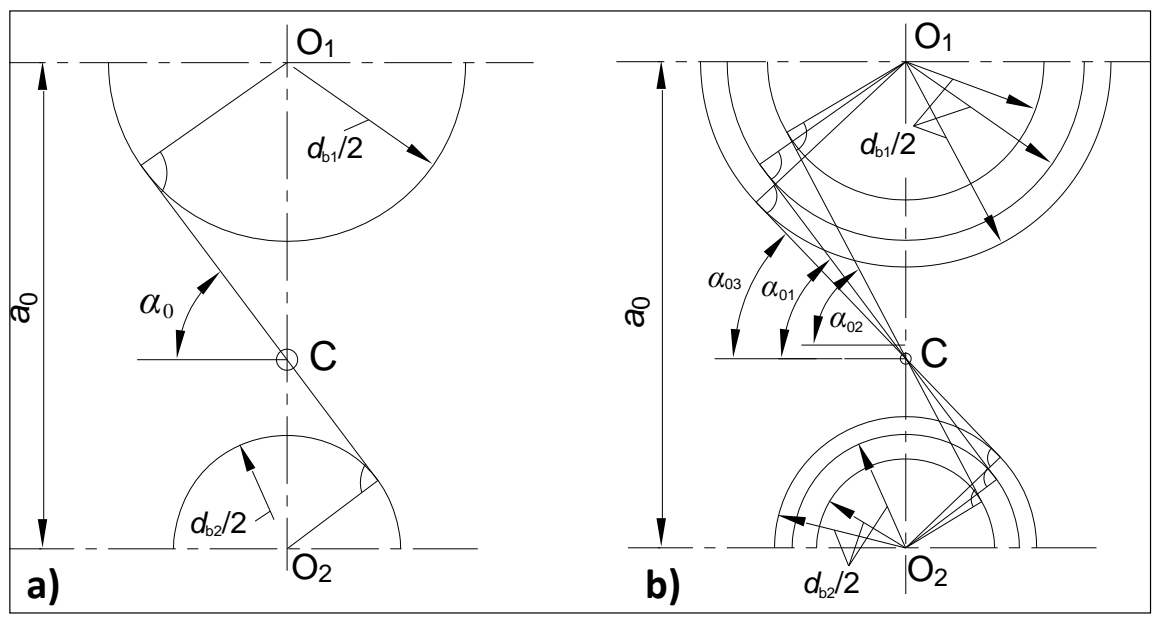

Fig. 2. Definition of the base profile angle

ameters [5-10, 12, 13]. The line of action and the common tangents of the rolling circles are called the profile angle $\left(\alpha_{g}\right)$. The angle which belongs to the pitch circles is called base profile angle $\left(\alpha_{0}\right)[5-10,12,13]$.

In Fig. $2 \mathrm{a}$ the determination of the base profile angle can be seen. In Fig. $2 b$ the modification of the base circle can be seen in the function of the modification of the base profile angle. If the base circle diameter is changed the generation circle of the involute profile curve will be changed because the base circle and the generation circle are the same $[6,9,10,12,13]$. By changing of the generation circle the shape of the involute curve will be changed that is why the curvature relations will be changed. This changing will modify the TCA parameters of the gear pairs.

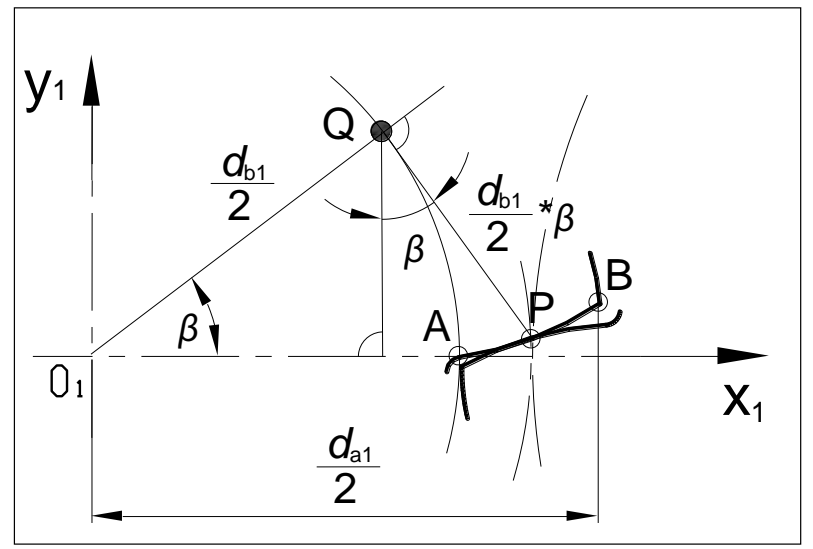

Fig. 3. Determination of the involute profile curve 


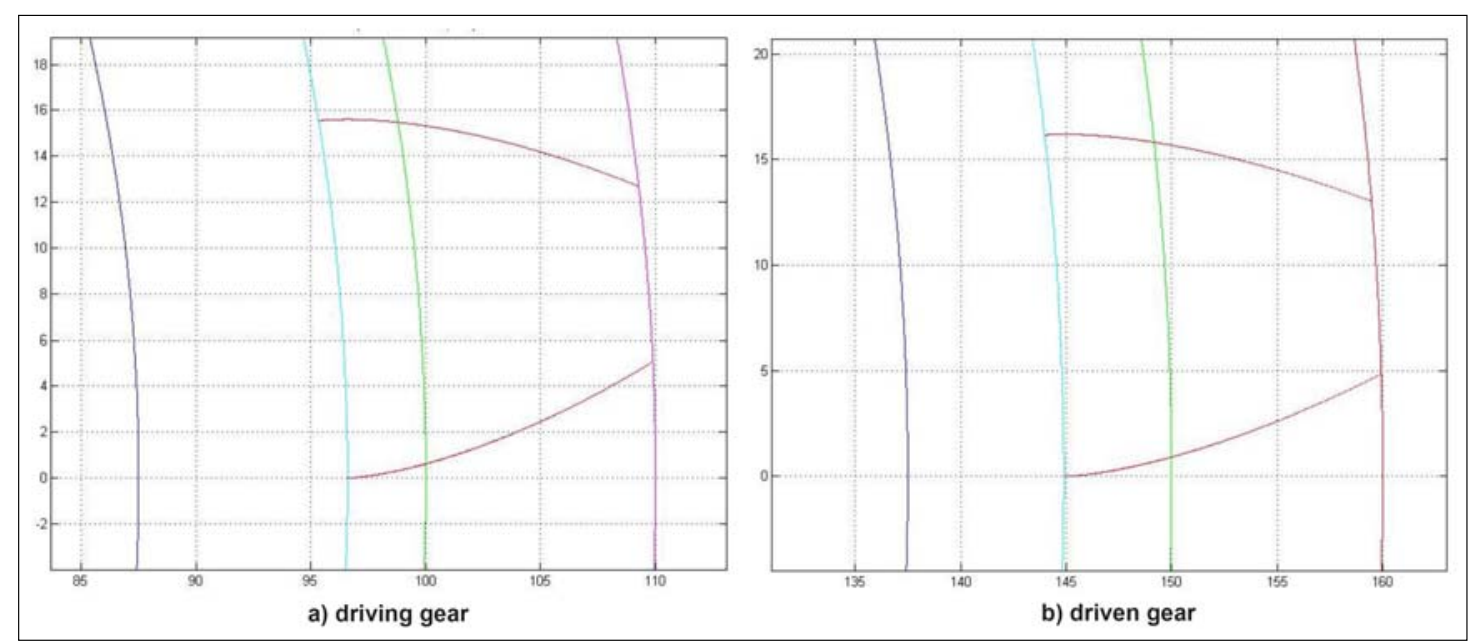

Fig. 4. Determining of the involute tooth profiles in a concrete case $\left(m=10 \mathrm{~mm}, z_{1}=20, z_{2}=30 . \alpha_{0}=15^{\circ}\right)$

necessary designing formulas and based on the input gear parameters (tooth numbers and module) the software could calculate the necessary gear parameters and determine the involute profile curve. This software was helpful in the modelling and designing process $[1,2]$ (Fig. 4).

Table 1. The calculated parameters of the gear pairs

\begin{tabular}{|c|c|c|c|c|c|}
\hline The main parameters of the gear pairs & Gear drive I & Gear drive II & Gear drive III & Gear drive IV & Gear drive $\mathrm{V}$ \\
\hline Base profile angle $\left(\alpha_{0}\right)\left[^{\circ}\right]$ & 14.5 & 15 & 18 & 20 & 22 \\
\hline Axial module (mm) & & & 10 & & \\
\hline Number of tooth of the driving gear $\left(z_{1}\right)$ & & & 20 & & \\
\hline Number of tooth of the driven gear $\left(z_{2}\right)$ & & & 30 & & \\
\hline Standard centre distance $\left(a_{0}\right)(\mathrm{mm})$ & & & 250 & & \\
\hline Addendum $\left(h_{a}\right)[\mathrm{mm}]$ & & & 10 & & \\
\hline Bottom clearance $(c)[\mathrm{mm}]$ & & & 2 & & \\
\hline Dedendum $\left(h_{f}\right)[\mathrm{mm}]$ & & & 12.5 & & \\
\hline Circular pitch $\left(t_{0}\right)[\mathrm{mm}]$ & & & 31.415 & & \\
\hline $\operatorname{Backlash}\left(j_{s}\right)[\mathrm{mm}]$ & & & 1.570 & & \\
\hline Whole depth $(h)[\mathrm{mm}]$ & & & 22.5 & & \\
\hline Working depth $\left(h_{w}\right)[\mathrm{mm}]$ & & & 20 & & \\
\hline Tooth thickness $\left(S_{a x_{1}}\right)[\mathrm{mm}]$ & & & 14.922 & & \\
\hline Pitch circle diameter of the driving gear $\left(d_{1}\right)[\mathrm{mm}]$ & & & 200 & & \\
\hline Tip circle diameter of the driving gear $\left(d_{a 1}\right)[\mathrm{mm}]$ & & & 220 & & \\
\hline Root circle diameter of the driving gear $\left(d_{f_{1}}\right)[\mathrm{mm}]$ & & & 175 & & \\
\hline Basic circle diameter of the driving gear $\left(d_{b_{1}}\right)[\mathrm{mm}]$ & 193.62 & 193.18 & 190.21 & 187.93 & 185.43 \\
\hline Pitch circle diameter of the driven gear $\left(d_{2}\right)[\mathrm{mm}]$ & & & 300 & & \\
\hline Tip circle diameter of the driven gear $\left(d_{a_{2}}\right)[\mathrm{mm}]$ & & & 320 & & \\
\hline Root circle diameter of the driven gear $\left(d_{f_{2}}\right)[\mathrm{mm}]$ & & & 275 & & \\
\hline Basic circle diameter of the driven gear $\left(d_{b_{2}}\right)[\mathrm{mm}]$ & 290.44 & 289.77 & 285.31 & 281.90 & 278.15 \\
\hline Transmission ratio $(i)$ & & & 1.5 & & \\
\hline
\end{tabular}




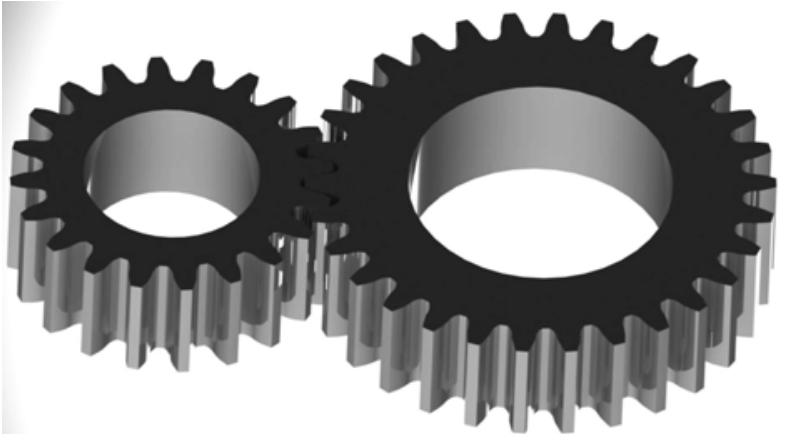

Fig. 5. Generation of the CAD model of the gear pairs
The base profile angles have been selected following the suggestions of $[5,6,12,13]$. After the calculation and the profile determination the CAD model of the gear pairs has been generated by SolidWorks software (Fig. 5). Interpolation B spline curve has been fixed to the received profile points.

\section{Analysis of the TCA parameters by the modification of the base profile angle}

After the generation of the CAD models of the analyzed gear pairs the following step is the adoption of

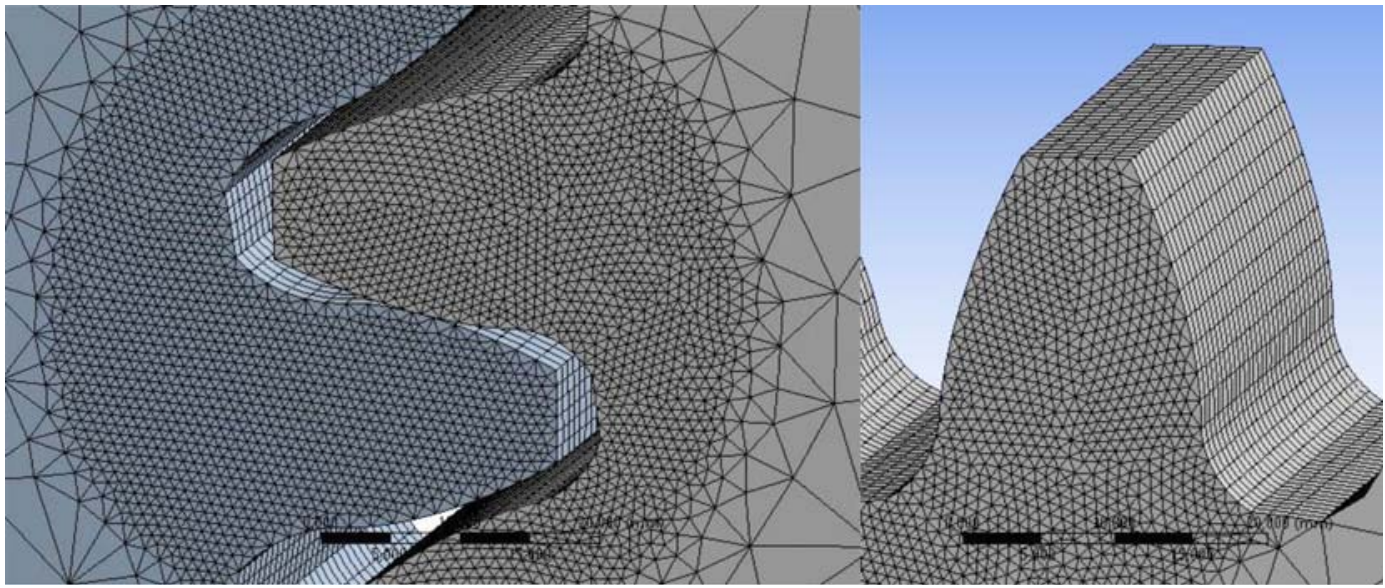

Fig. 6. Adoption of the finite element meshing

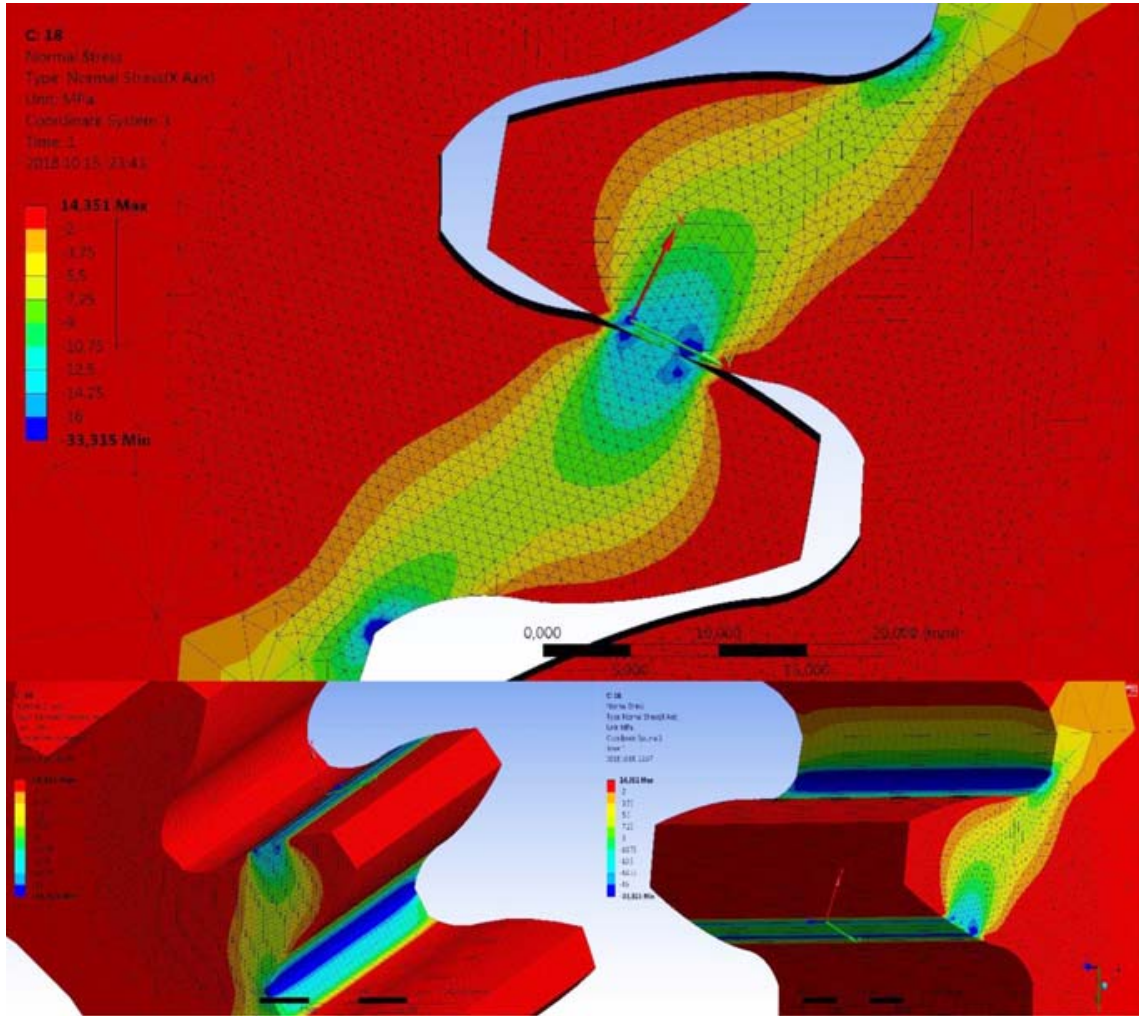

Fig. 7. Normal stress distribution on the contact zone and the surfaces of the gear pairs. $\left(\mathrm{m}=10 \mathrm{~mm}, z_{1}=20, z_{2}=30, \alpha_{0}=18^{\circ}\right)$ 
the necessary coordination systems for the analysis. Two coordinate systems are needed on the axis of rotation of the gears and one other coordination system is needed on the tooth contact zone [7-10]. The one axis of the latter coordinate system would be perpendicular to the profile surface of the gear [7-10]. It is important because of the analysis of the normal mechanical parameters.

For the analyses fine triangle meshing has been applied on the tooth contact zone (Fig. 6) [7-9]. The applied meshing density has been $0.8 \mathrm{~mm}$. On the contact zone structural meshing has been applied by sphere of influence's structure. On the outside zones automatic meshing has been applied (Fig. 6).

The adopted surface meshing has been divided equally along the tooth length by the sweep operation (Fig. 6).
Table 2. Parameters of the applied material (structural steel)

\begin{tabular}{lc}
\hline Density & $7850 \mathrm{~kg} / \mathrm{m}^{3}$ \\
Yield limit & $250 \mathrm{MPa}$ \\
Ultimate strength & $460 \mathrm{MPa}$ \\
\hline
\end{tabular}

The driving tooth gear has been loaded by $700 \mathrm{Nm}$ moment. Five degrees of freedom have been fixed on the driving gear, only the turning motion around the axis of rotation has been let. The driven gear has been totally fixed.

\subsection{Analysis of the normal stress}

The normal stress is interpreted on perpendicular direction of the tooth surface $[7-9,11,14,15]$. This direction is the most determinative from the aspect of

Fig. 8. Normal stress results for every gear pairs

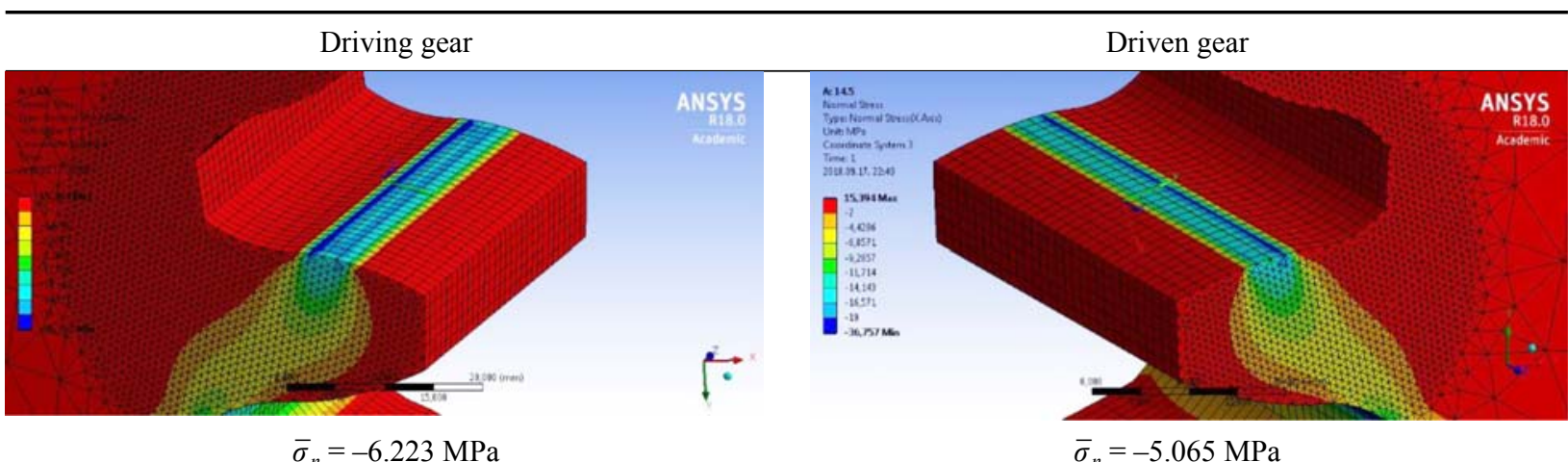

$\alpha_{0}=14.5^{\circ}$

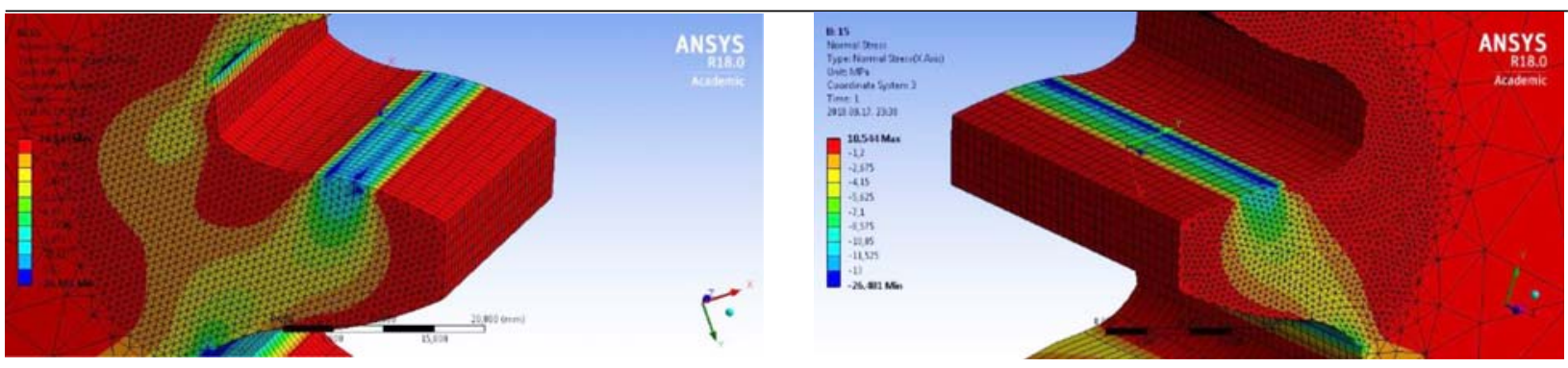

$\bar{\sigma}_{n}=-3.299 \mathrm{MPa}$

$\bar{\sigma}_{n}=-3.843 \mathrm{MPa}$

$\alpha_{0}=15^{\circ}$

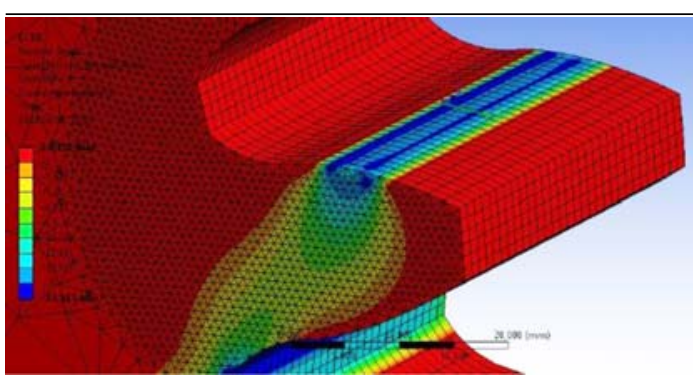

$\bar{\sigma}_{n}=-5.193 \mathrm{MPa}$

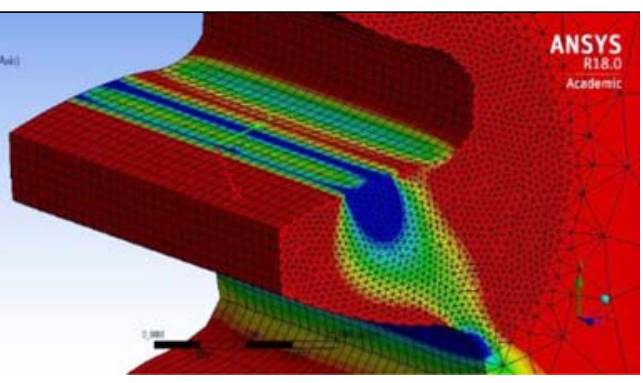

$\bar{\sigma}_{n}=-5.135 \mathrm{MPa}$

$\alpha_{0}=18^{\circ}$ 
Fig. 8. (cont'd)

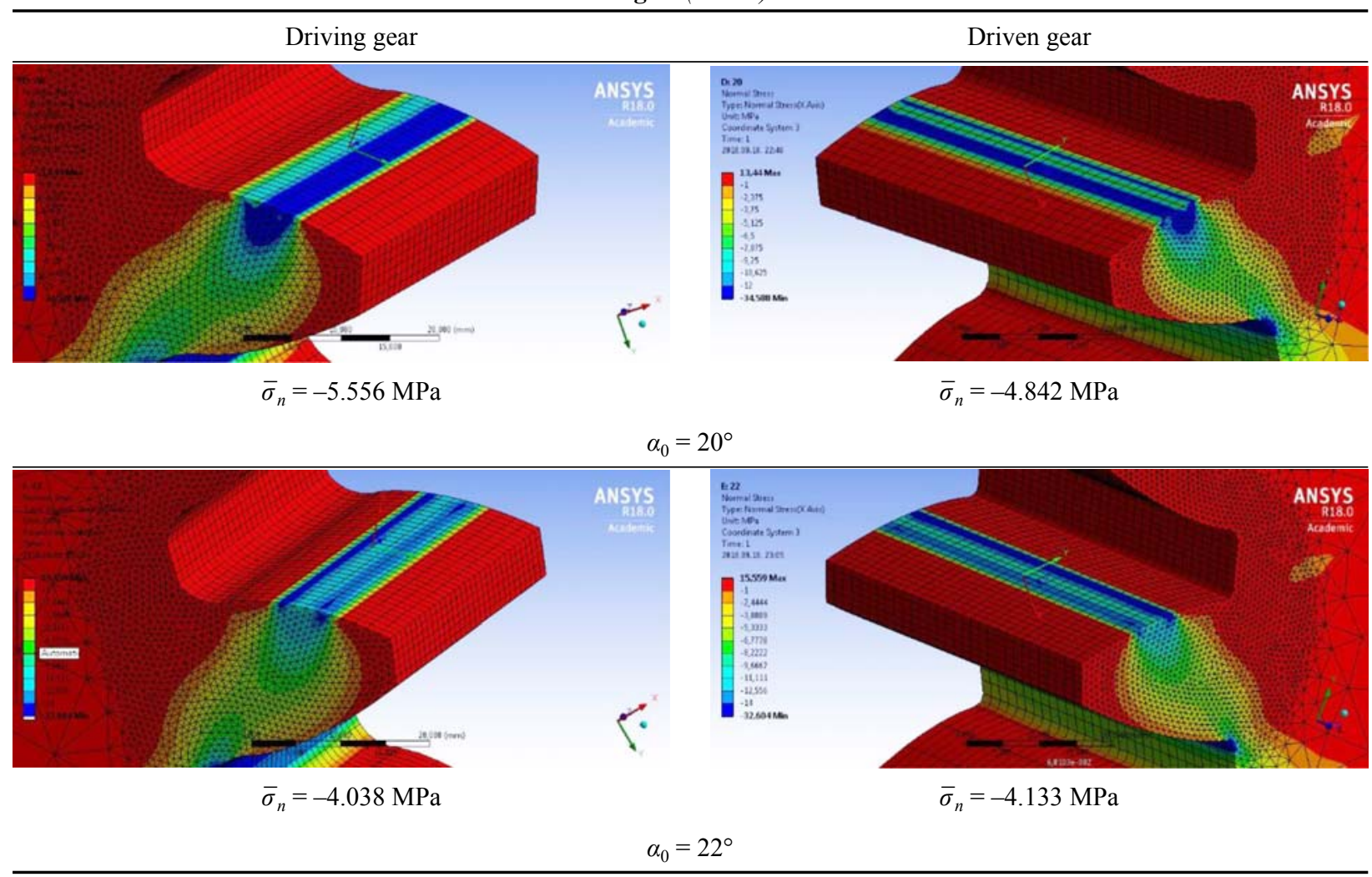

tooth deformation. This normal stress has been calculated for the tooth contact zone (Fig. 7).

In Figs 8 and 9 the normal stress distributions can be seen in the function of the base profile angle. According to the normal stress the Gear drive II (Table 1) is the most appropriate because the normal stress in absolute value is the lowest in this case (Fig. 9). The highest normal stress values are applied in the case of the application of Gear drive I. (Fig. 9).

\subsection{Analysis of the normal elastic strain}

The normal elastic strain has been calculated for the tooth contact zone (Fig. 10). It is defined on perpendicular direction for the tooth surface [7-9, 11, 14, 15].

In Figs 11 and 12 the normal elastic strain distributions can be seen in the function of the base profile angle. According to the normal elastic strain the Gear drive II (Table 1) is the most appropriate because the

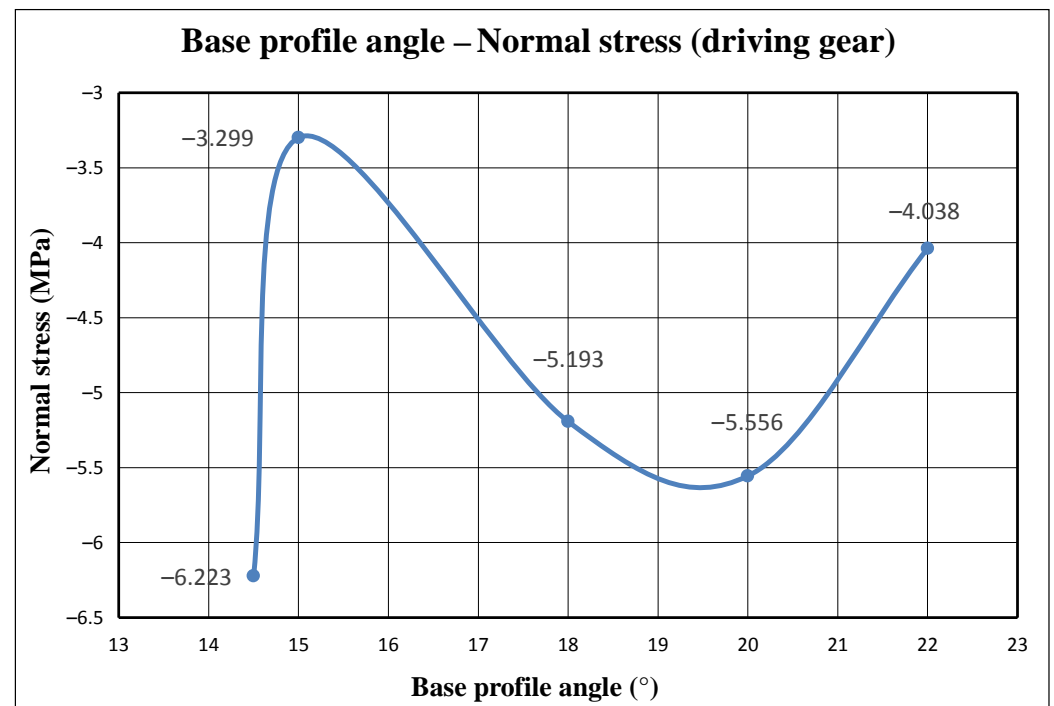

Fig. 9a. The normal stress results in the function of the base profile angle, driving gear 


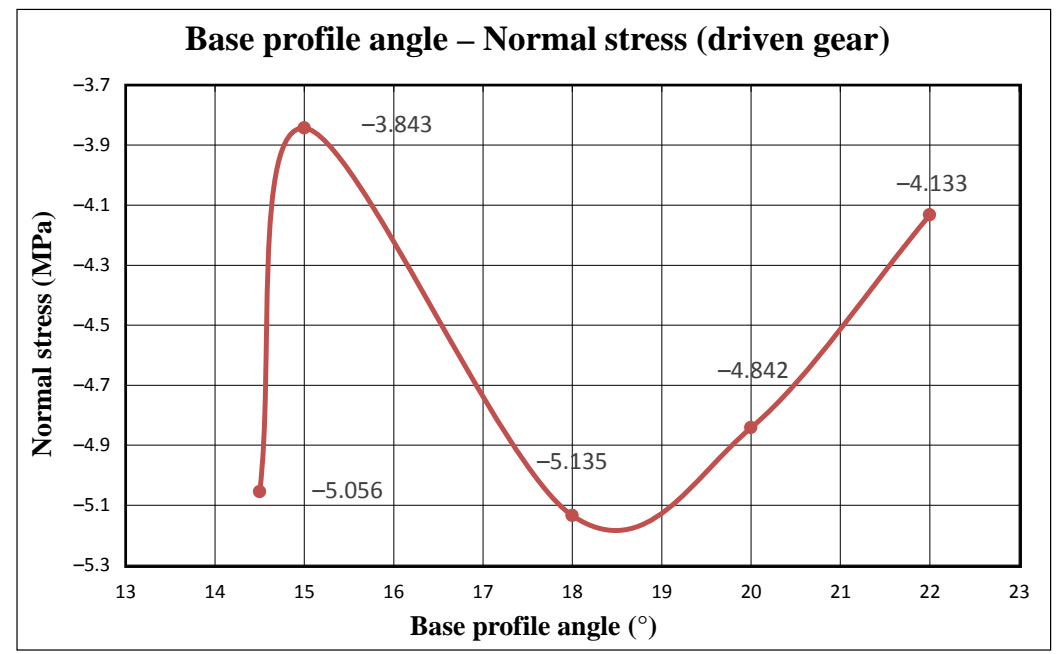

Fig. 9b. The normal stress results in the function of the base profile angle, driven gear

normal elastic strain in absolute value is the lowest in this case (Fig. 12). The highest normal stress values are applied in the case of the application of Gear drive IV. (Figure 12).

\subsection{Analysis of the normal deformation}

The normal deformation has been analyzed into the $x$ direction, which is perpendicular to the contact surfaces [14]. This direction is the most determinative because the main deformation is applied into the perpendicular direction of the contact surfaces [4, 9] (Fig. 13).

In Figs 14 and 15 the normal deformation distributions can be seen in the function of the base profile angle. According to the normal deformation the Gear drive II (Table 1) is the most appropriate because the normal deformation in absolute value is the lowest in

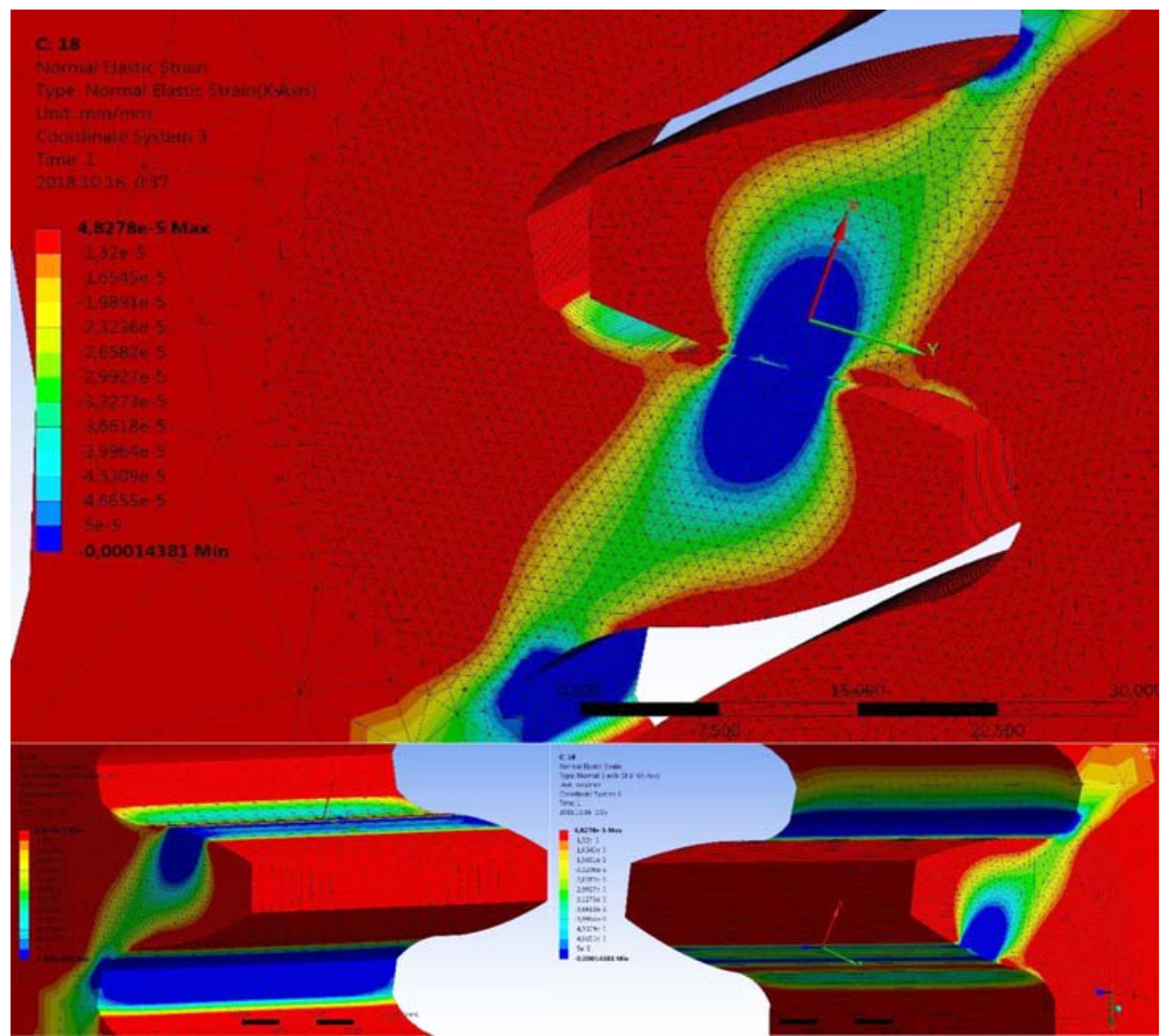

Fig. 10. Normal elastic strain distribution on the contact zone and the surfaces of the gear pairs $\left(m=10 \mathrm{~mm}, z_{1}=20, z_{2}=30 . \alpha_{0}=18^{\circ}\right)$ 
Fig. 11. Normal elastic strain results for every gear pairs

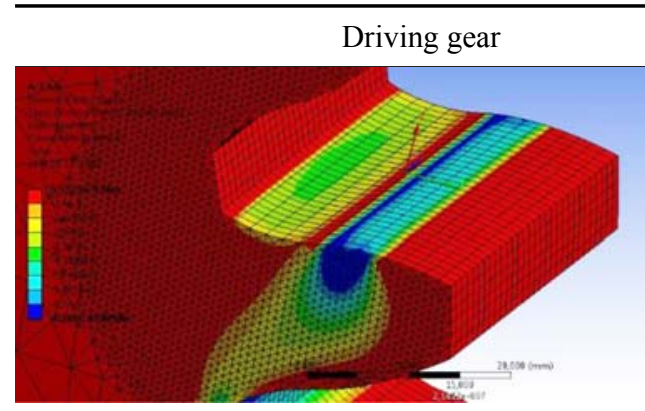

$\bar{\varepsilon}_{n}=-0.000024$

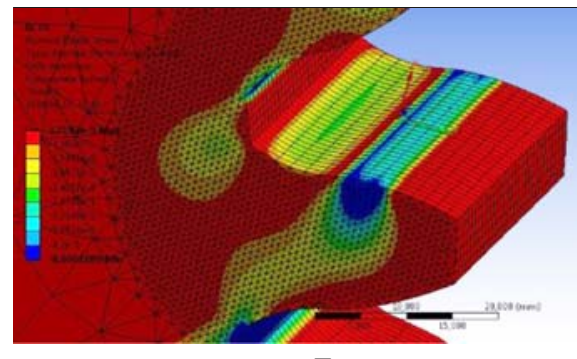

$\bar{\varepsilon}_{n}=-0.0000134$
Driven gear

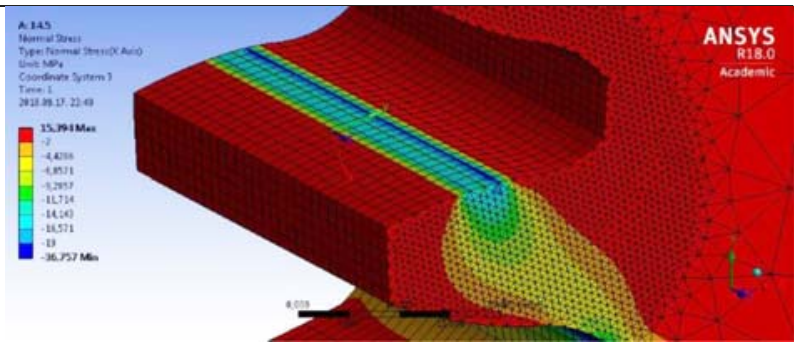

$\bar{\varepsilon}_{n}=-0.0000202$

$\alpha_{0}=14.5^{\circ}$

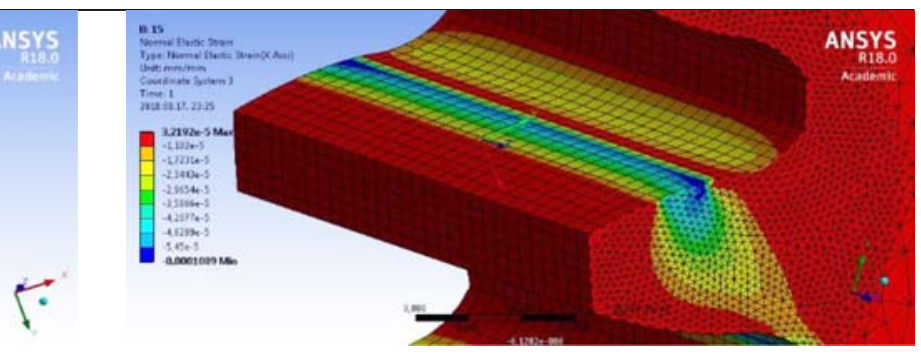

$\bar{\varepsilon}_{n}=-0.0000184$

$\alpha_{0}=15^{\circ}$

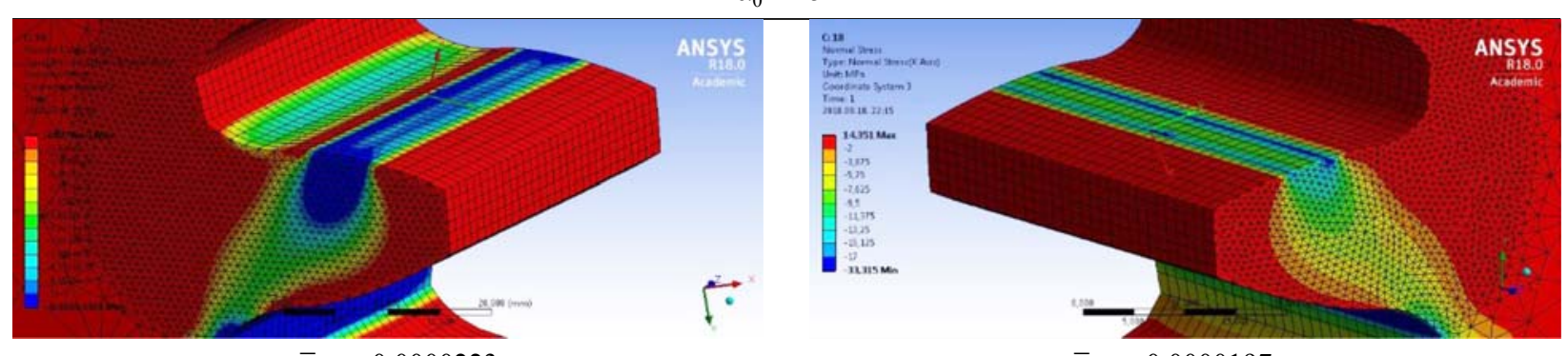

$\bar{\varepsilon}_{n}=-0.0000197$

$\alpha_{0}=18^{\circ}$

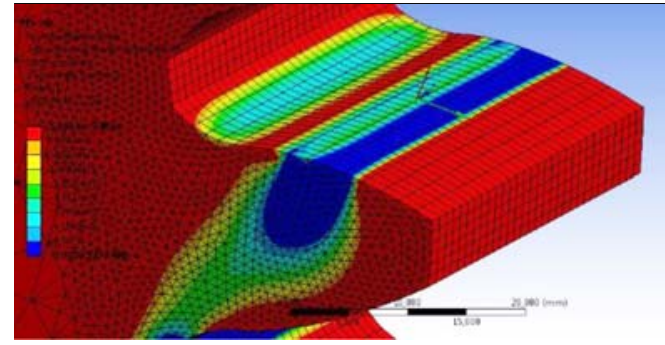

$\bar{\varepsilon}_{n}=-0.0000225$

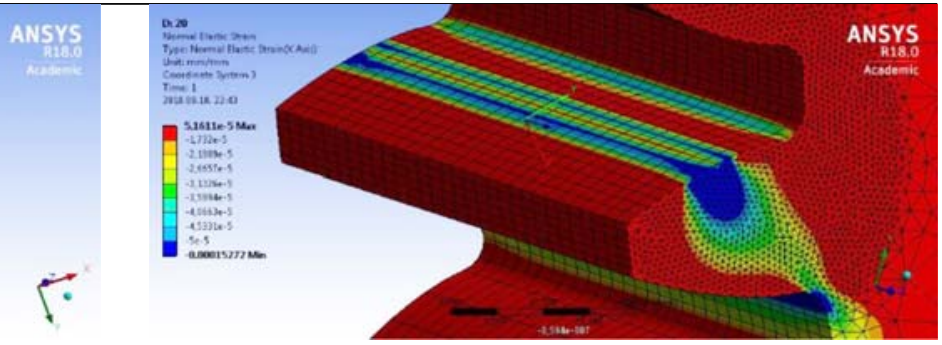

$\bar{\varepsilon}_{n}=-0.0000193$

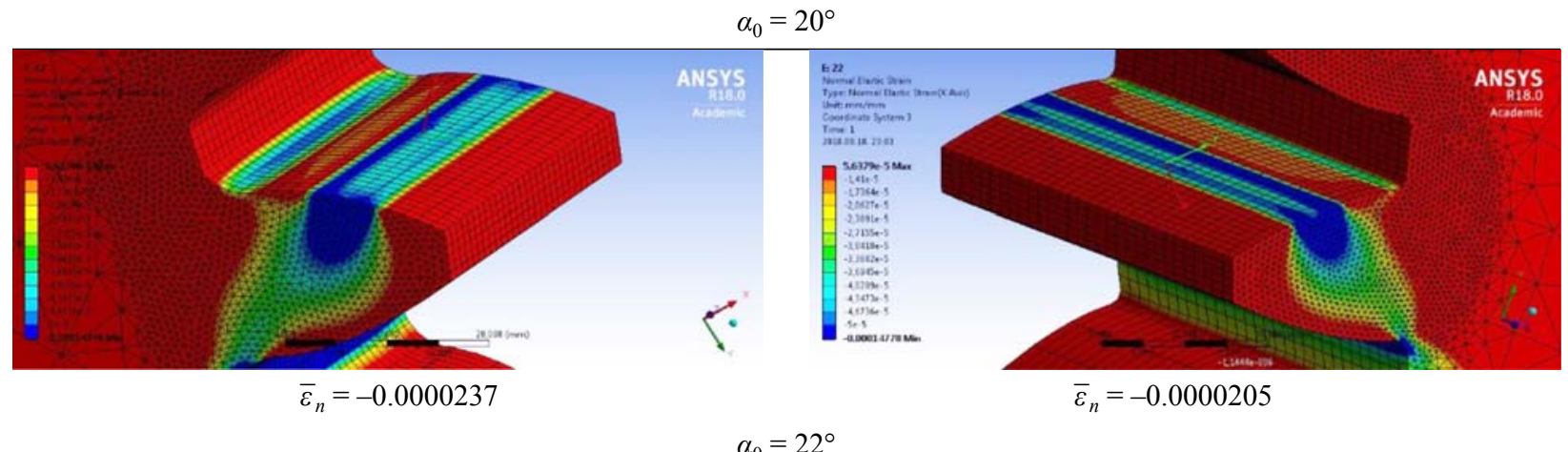

$\alpha_{0}=22^{\circ}$ 


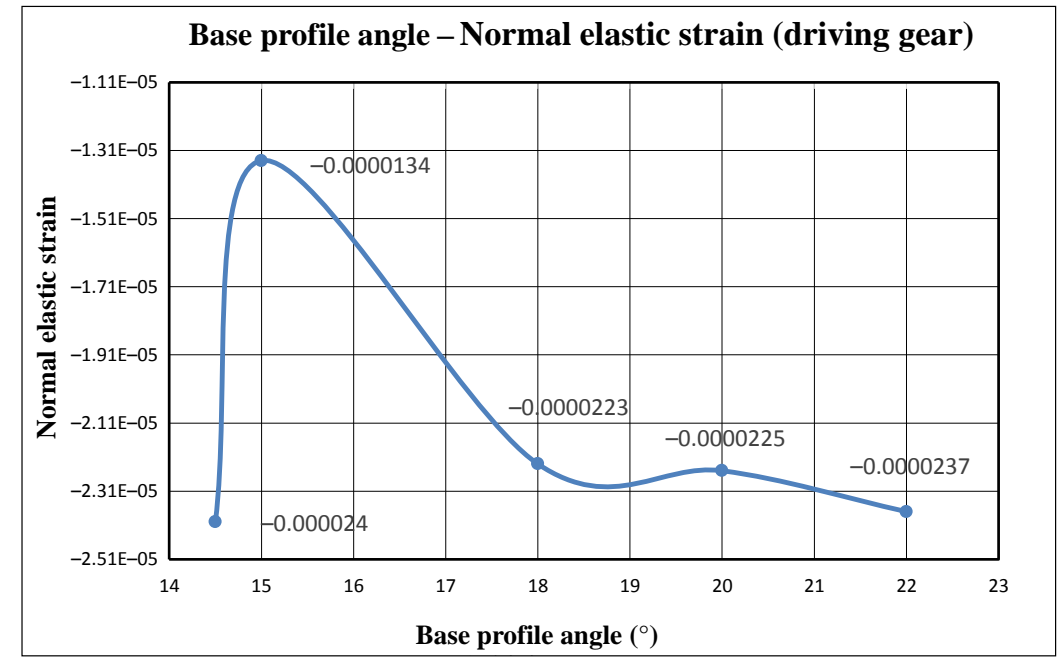

Fig. 12a. The normal stress results in the function of the base profile angle, driving gear

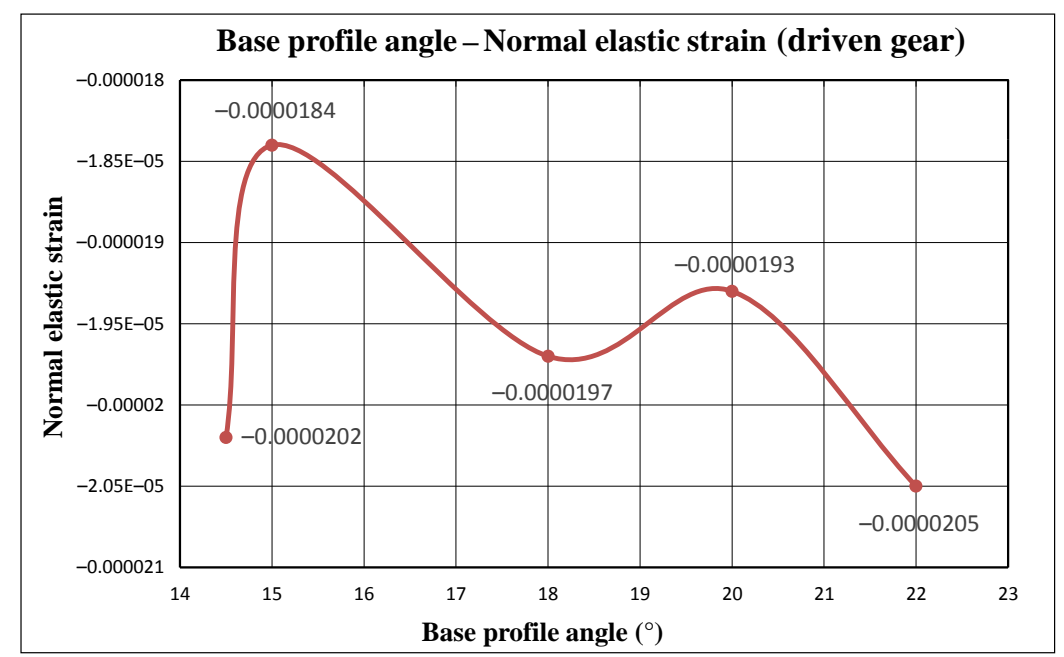

Fig. 12b. The normal stress results in the function of the base profile angle, driven gear

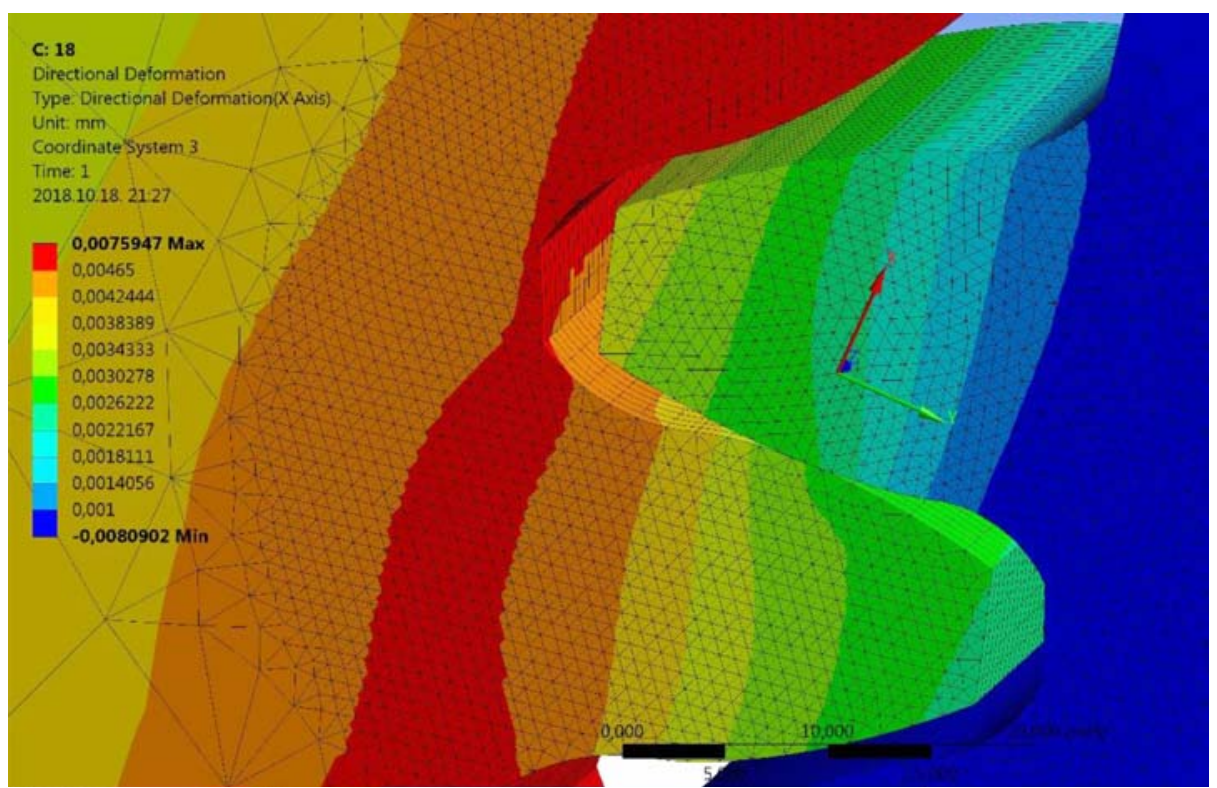

Fig. 13. Normal deformation distribution on the contact zone and the surfaces of the gear pairs. $\left(m=10 \mathrm{~mm}, z_{1}=20, z_{2}=30, \alpha_{0}=18^{\circ}\right)$ 


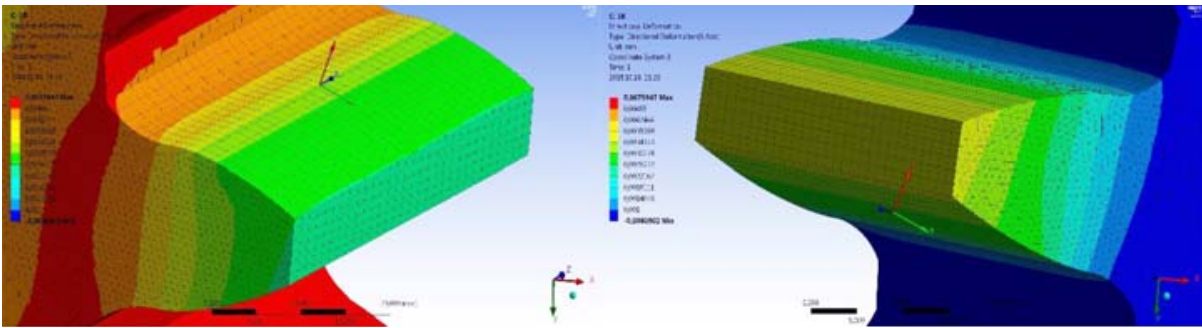

Fig. 13. (cont'd)

Fig. 14. Normal deformation results for every gear pairs

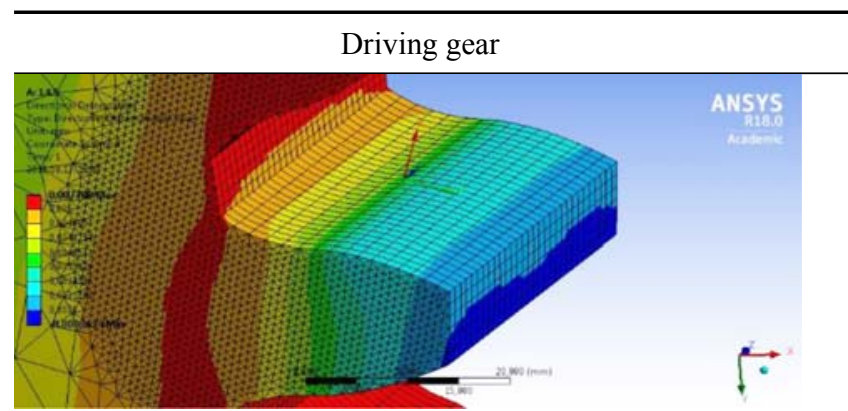

$\bar{u}_{x}=-0.00322 \mathrm{~mm}$
Driven gear

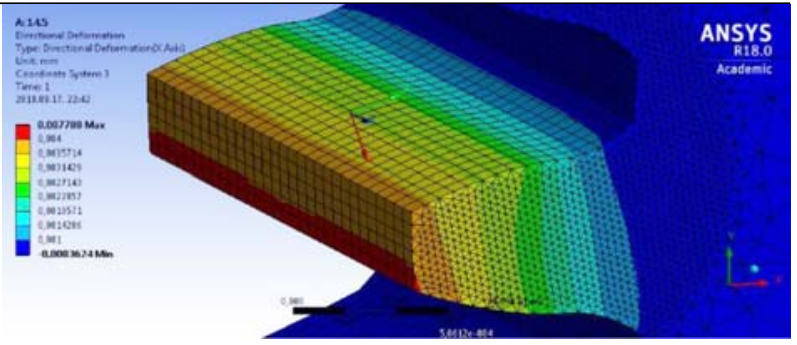

$\bar{u}_{x}=-0.00286 \mathrm{~mm}$

$\alpha_{0}=14.5^{\circ}$

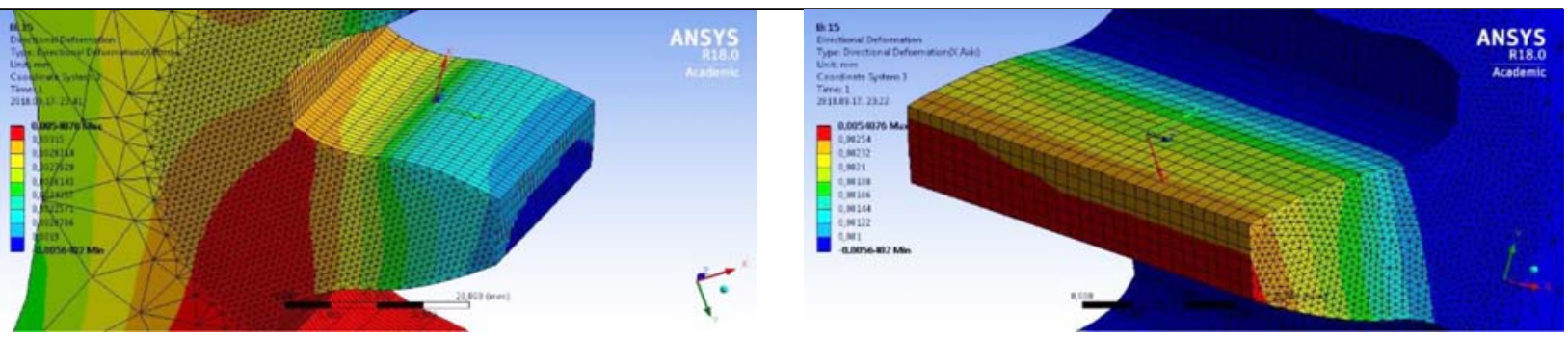

$\bar{u}_{x}=-0.00216 \mathrm{~mm}$

$\bar{u}_{x}=-0.00203 \mathrm{~mm}$

$\alpha_{0}=15^{\circ}$

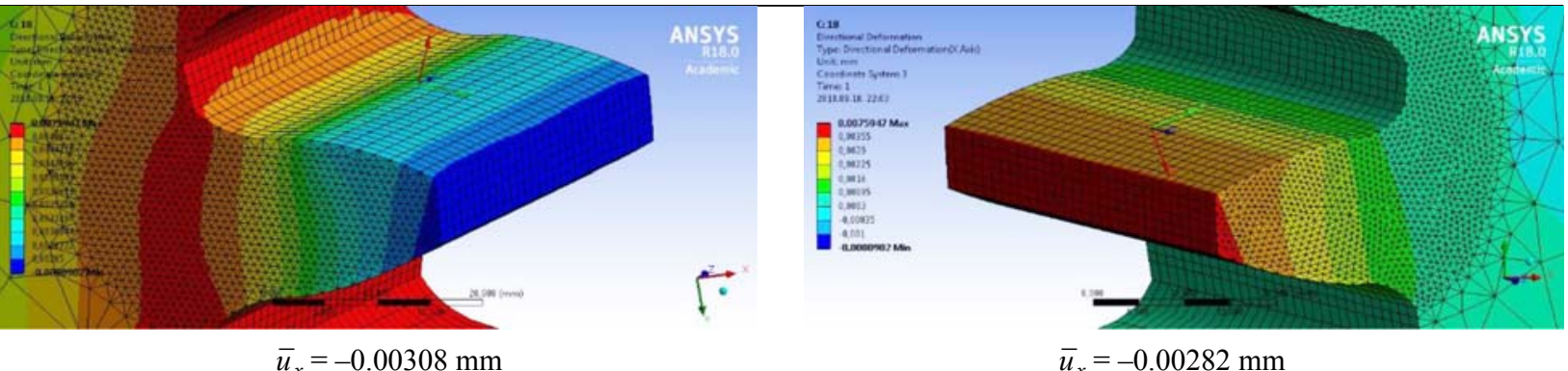

$\alpha_{0}=18^{\circ}$

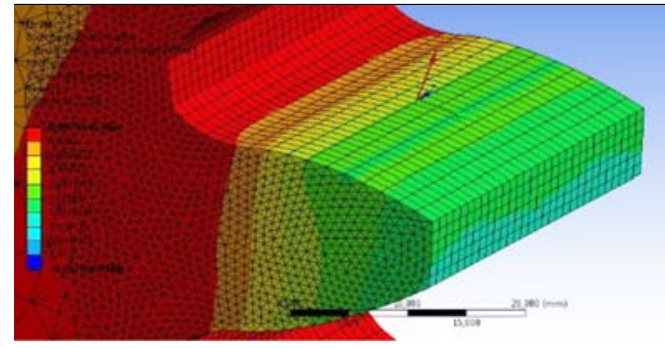

$\bar{u}_{x}=-0.00311 \mathrm{~mm}$

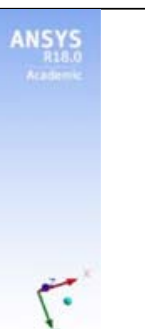

$\because$

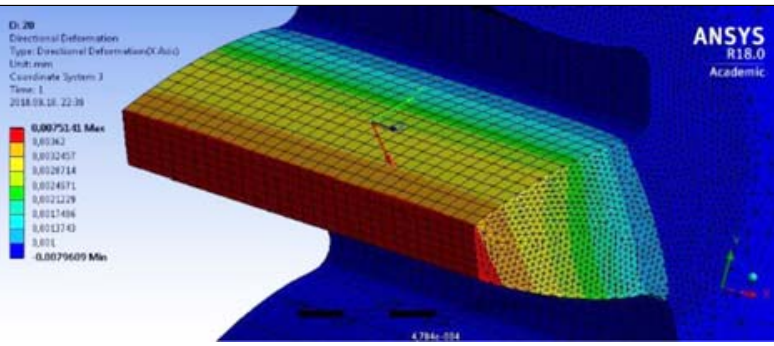

$\bar{u}_{x}=-0.00281 \mathrm{~mm}$

$$
\alpha_{0}=20^{\circ}
$$


Fig. 14. (cont'd)

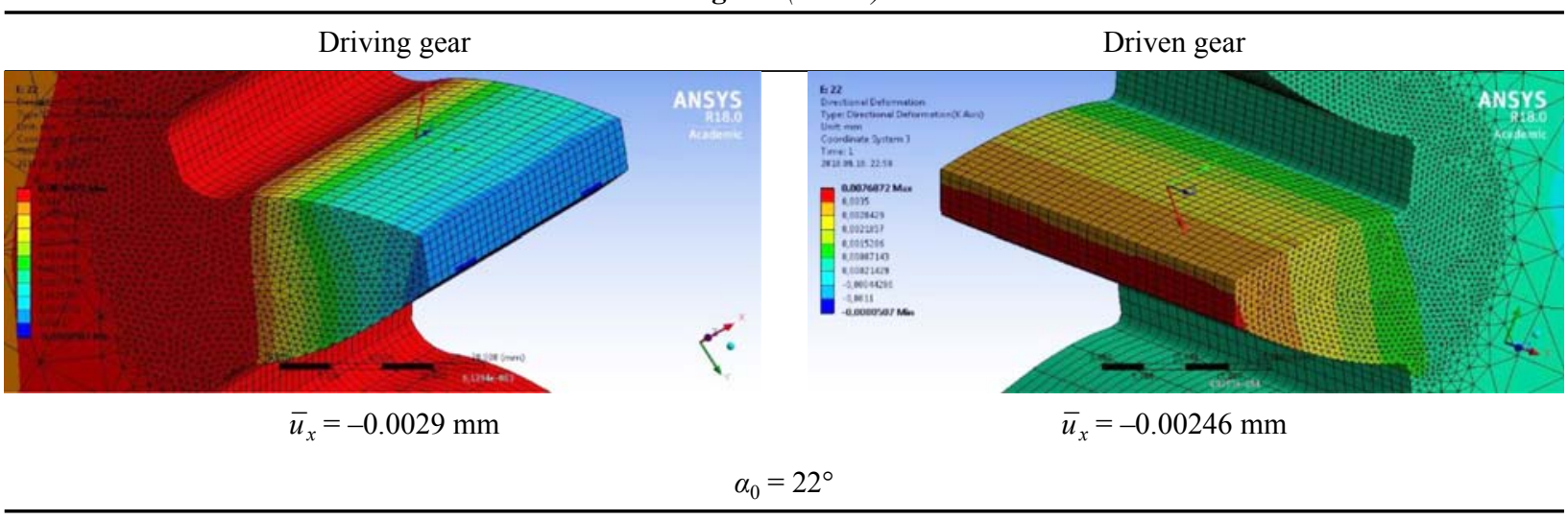

this case (Fig. 14). The highest normal deformation values are applied in the case of the application of Gear drive III. and IV. (Fig. 15).

\section{Conclusion}

The aim of this research is the analysis of the TCA parameters (normal stress, normal elastic strain, normal

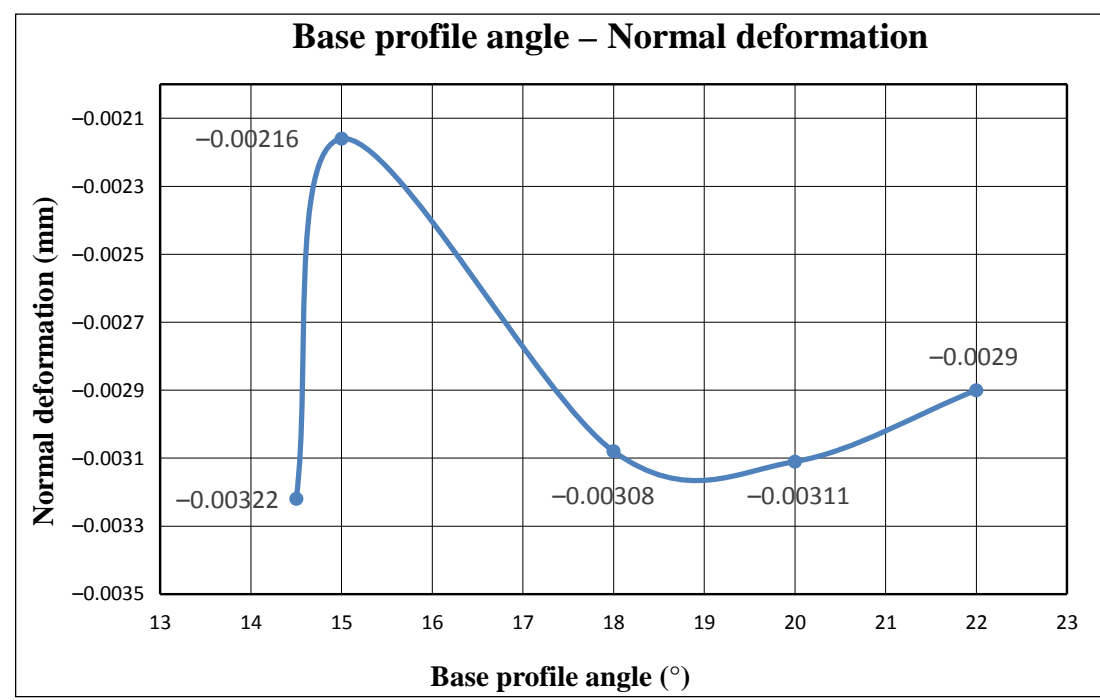

Fig. 15a. The normal deformation results in the function of the base profile angle, driving gear

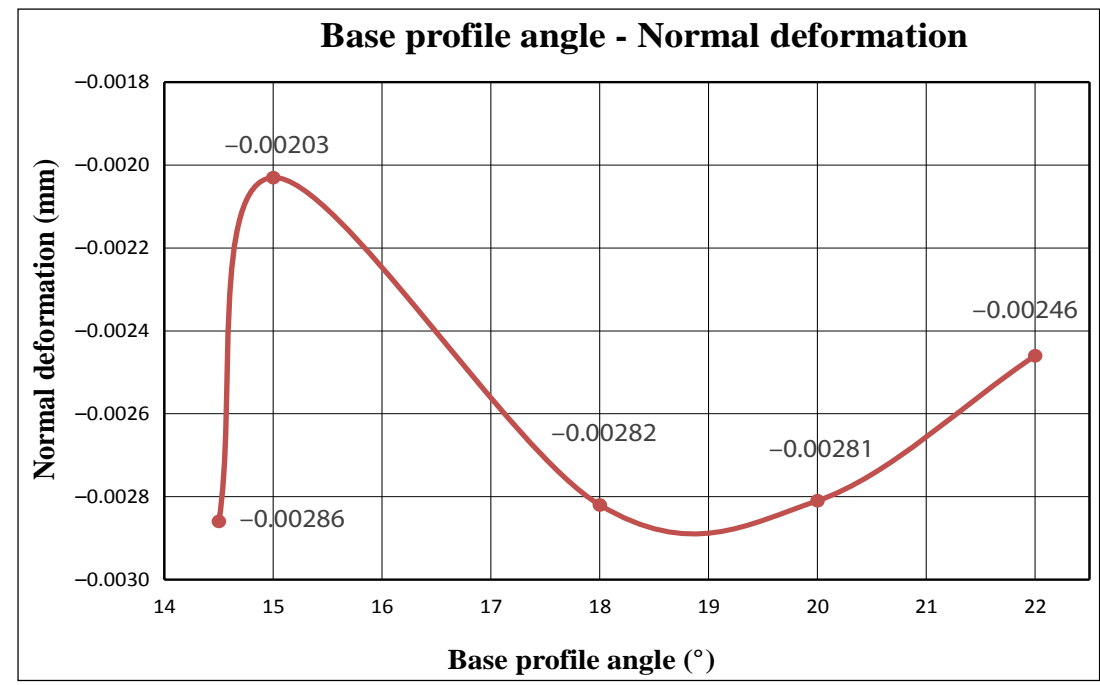

Fig. 15b. The normal deformation results in the function of the base profile angle, driven gear 
deformation) in the function of the base profile angle. This angle influenced the shape of the connection impression and the mechanical parameters on the connection zone, that is why the appropriate selection is important in the case of geometric designing.

Previously, the geometric designing and the CAD modelling of the x-zero gear drives were needed for the designing of the analysis. We have worked out a new type computer program with which the designing process of the gear pairs could be eased.

After the calculation of the geometric parameters and the profile points the following step is the CAD modelling process. Interpolation B-spline curve has to be fit on the calculated profile points. Using of this designing process five types of $\mathrm{x}$-zero gear drive have been designed with different base profile angles. All the other parameters have been the same on every gear.

Before the TCA the adoption of the necessary coordinate systems and the setting of the load and boundary conditions are necessary. The adoption of the finite element mesh is needed for the analysis, but dense meshing is suggested into the contact teeth because of the more accurate results.

Based on the received TCA parameters of the gear pairs we can determine that the application of the $15^{\circ}$ base profile angle is the best choice in the case of the analyzed gear pairs. By using this angle the TCA parameters will be lower than in the other cases.

\section{Acknowledgements}

Supported BY the ÚNKP-18-4 New National Excellence Program of the Ministry of Human Capacities.

\section{References}

[1] Bodzás S. (2017), Computer aided designing and modelling of x-zero gear drive. International Review of Applied Sciences and Engineering, 8(1), 93-97. DOI: 10.1556/1848.2017.8.1.13
[2] Bodzás S. (2019), Computer aided designing and modelling of spur gear pairs having normal and modified straight teeth. International Review of Applied Sciences and Engineering, 10(2), 157-163. DOI: 10.1556/1848.2019.0019

[3] Dudás I. (2011), Gépgyártástechnológia III., A. Megmunkáló eljárások és szerszámaik, B. Fogazott alkatrészek gyártása és szerszámaik. Müszaki Kiadó, Budapest

[4] Dudás L. (1991), Kapcsolódó felületpárok gyártásgeometriai feladatainak megoldása az elérés modell alapján. Kandidátusi értekezés, Budapest, TMB, p. 144, 2005. 06. 29.

[5] Dudley D. W. (1962), Gear Handbook. McGraw Hill Book Co., New York-Toronto-London

[6] Erney Gy. (1983), Fogaskerekek. Müszaki Könyvkiadó, Budapest, p. 460.

[7] Fuentes A., Ruiz-Orzaez R., Gonzalez-Perez I. (2014), Computerized design, simulation of meshing, and finite element analysis of two types of geometry of curvilinear cylindrical gears. Computer Methods Apply Mechanical Engineering, Elsevier, pp. 321-339.

[8] Gonzalez-Perez I., Roda-Casanova V., Fuentes A. (2015), Modified geometry of spur gear drives of compensation of shaft deflections. Meccanica, 1855-1867, DOI: 10.1007/ s11012-015-0129-9

[9] Litvin F. L., Fuentes A. (2004), Gear Geometry and Applied Theory. Cambridge University Press, ISBN 9780 521815178

[10] Litvin F. L. (1972), A fogaskerékkapcsolás elmélete. Müszaki Könyvkiadó, Budapest

[11] Pálinkás S., Krállics Gy., Bézi Z. (2013), Modelling of Crown and Cold Rolled Aluminum Sheet. Materials Science Fórum, pp. 115-124.

[12] Rohonyi V. (1980), Fogaskerékhajtások. Müszaki Könyvkiadó, Budapest

[13] Terplán Z. (1975), Gépelemek IV. Kézirat, Tankönyvkiadó, Budapest, p. 220.

[14] Páczelt I., Szabó T., Baksa A. (2004), A végeselem módszer alapjai. Miskolci Egyetem, p. 243.

[15] Mankovits T., Szabó T., Kocsis I., Páczelt I. (2014), Optimization of the shape of axi-symmetric rubber bumpers. Strojniski Vestnik - Journal of Mechanical Engineering, 61-71. 